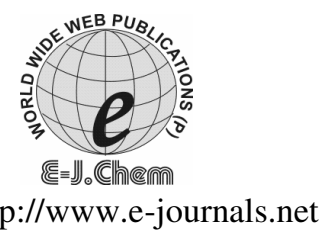

\title{
Bimetal Adsorption by Cottonseed Carbon: Equlibrium and Kinetic Studies
}

\author{
K. SRINIVASAN ${ }^{*}$ and E. SATHIYA \\ *Department of Chemistry, College of Engineering, \\ Anna University-CBE, Salem-636011, India. \\ Department of Chemistry, \\ Annai Mathammal Snheela Engineering College, \\ Erumapatty, Namakkal Dt. Tamilnadu, India. \\ srini_vasank@hotmail.com
}

Received 22 February 2009; Accepted 4 April 2009

\begin{abstract}
The simultaneous adsorption of $\mathrm{Pb}(\mathrm{II})$ and $\mathrm{Hg}$ (II) on cottonseed carbon (CSC) was employed for the removal of these metals from wastewater. The influence of various factors such as agitation time, $\mathrm{pH}$ and carbon dosage on the adsorption capacity has been studied. Langmuir and Freundlich equation could be used to interpret adsorption data. Sorption kinetics has indicated that reversible first order kinetics model could be applied with film diffusion as the controlling mechanism.
\end{abstract}

Keywords: Cottonseed Carbon, Lead(II) adsorption, Mercury(II) adsorption, Langmuir isotherm, Freundlich isotherm.

\section{Introduction}

Heavy metals are not biodegradable and tend to accumulate in living organisms, causing various diseases and disorders. Significant quantities of $\mathrm{Pb}(\mathrm{II})$ containing wastewater are introduced into water bodies from the effluents of storage batteries, pigments, protection of television picture tubes. The concentration of lead in water below the WHO standard $(5.0 \mathrm{mg} / \mathrm{L})$ cannot be considered as serious sources of lead intake ${ }^{1}$. Higher concentration of lead causes severe destruction of reproductive system, liver, brain and central nervous system.

Significant quantities of $\mathrm{Hg}(\mathrm{II})$ containing wastewater are introduced into water bodies from the effluent of industries which produce electrical equipments, paints, pesticides, pulp and paper, domestic thermometers, insecticides, fungicides, batteries and chlor-alkali plants. Mercury causes damage to the central nervous system and chromosomes, impairment of pulmonary function and kidney, chest pain and dyspnoea ${ }^{2,3}$. Higher dose may damage the liver ${ }^{4}$. These harmful effects of $\mathrm{Pb}(\mathrm{II})$ and $\mathrm{Hg}(\mathrm{II})$ necessitate its removal from wastewaters before release into streams. 
Many reports are available on the development of activated carbon from cheaper and readily available materials such as rice husk, coconut shell etc $^{5-7}$. In this connection it was proposed to make use of carbon from cottonseed, a waste agricultural byproduct, utilized for the simultaneous removal of $\mathrm{Pb}(\mathrm{II})$ and $\mathrm{Hg}$ (II) from water and wastewater.

\section{Experimental}

$50 \mathrm{~g}$ of dried cottonseeds treated with $200 \mathrm{~g}$ of sulphuric acid and then kept in an air oven maintained at $140-160{ }^{\circ} \mathrm{C}$ for a period of 24 hours. The product was washed with water to remove sulphuric acid and dried at $110{ }^{\circ} \mathrm{C}$ followed by soaking in $5 \% \mathrm{NaHCO}_{3}$ for a period 24 hours to eliminate any free acid as well as to covert any ion exchange sites on the carbon into sodium loaded sites. After soaking period, the material was washed with distilled water and then dried at $110{ }^{\circ} \mathrm{C}$. This material was sieved to particle sizes in the range (20-50) Mesh and used for simultaneous removal of $\mathrm{Pb}(\mathrm{II})$ and $\mathrm{Hg}(\mathrm{II})$. The carbon characteristics were found out using ISI-877 procedures and given in Table 1. It could be seen that this carbon contains sufficient bulk density, phenol number, surface area and ion exchange capacity so that it can be used for adsorption purposes.

Table 1. Carbon characteristics (CSC).

\begin{tabular}{clc}
\hline S. No. & \multicolumn{1}{c}{ Description } & Results \\
\hline 1 & Bulk density, g/cc & 0.54 \\
2 & Moisture content, \% & 12.32 \\
3 & Ash, \% & 8.00 \\
4 & Matter soluble in water, \% & 2.37 \\
5 & Matter soluble in acid, \% & 5.27 \\
6 & Decolorizing power, mg/g & 0.15 \\
7 & Phenol numbers & 15 \\
8 & Ion exchange capacity & 0.294 \\
9 & milli equivalent / g & 545.6 \\
10 & Surface area sq.m/g & 1.15 \\
11 & Iron contents, \% & 6.50 \\
\hline
\end{tabular}

\section{Batch mode studies}

A stock solution of $100 \mathrm{mg} / \mathrm{L}$ of $\mathrm{Pb}$ (II) and $100 \mathrm{mg} / \mathrm{L}$ of $\mathrm{Hg}$ (II) was prepared by using analar grade lead nitrate and mercuric chloride. Batch experiments have been conducted for the simultaneous determination of lead and mercury. Experiments have been conducted with $100 \mathrm{~mL}$ of $10 \mathrm{mg} / \mathrm{L}$ of lead and $10 \mathrm{mg} / \mathrm{L}$ of mercury taken together in $300 \mathrm{~mL}$ stopper bottles. Solutions were equilibrated in mechanical shaker. At the end of equilibration period the solutions were filtered using a G3 crucible if necessary and the concentration of $\mathrm{Pb}$ (II) and $\mathrm{Hg}$ (II) ions were established simultaneously by Atomic Absorption spectrophotometer.(Elico Model 60).

\section{Results and Discussion}

\section{Effect of agitation time}

Figure 1 shows the effect of agitation time on the simultaneous removal of lead and mercury by CSC. The extent of removal increases with time and attains equilibrium in 3 hours for both metals, for an initial concentration of $10 \mathrm{mg} / \mathrm{L}$ of $\mathrm{Pb}(\mathrm{II})$ and $\mathrm{Hg}$ (II) and for a carbon dosage $100 \mathrm{mg} / 100 \mathrm{~mL}$. It could be seen that $90-92 \%$ of $\mathrm{Pb}$ (II) and $\mathrm{Hg}$ (II) was removed on CSC. It could be seen that $\mathrm{Hg}$ (II) removal was more when compared with $\mathrm{Pb}$ (II). 


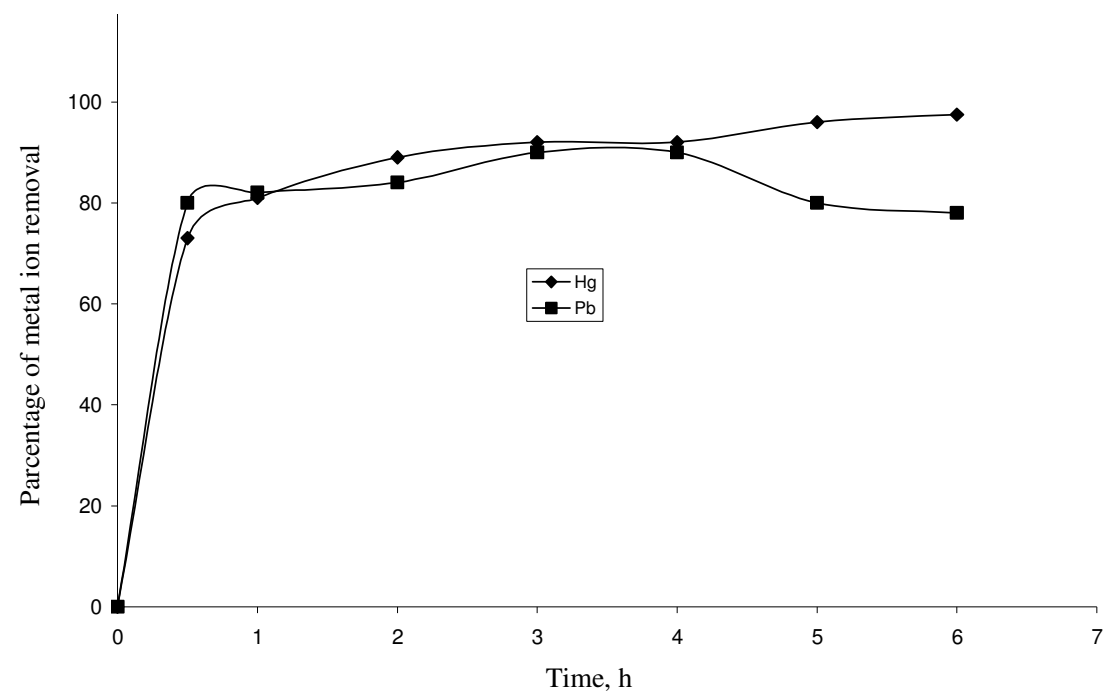

\section{Effect of $p H$}

Figure 1. Effect of equilibiration time.

Figure 2 presents the effect of initial $\mathrm{pH}$ on the simultaneous removal of lead and mercury by CSC. It is evident that maximum removal of lead occurred at $\mathrm{pH} 4$ to 6 and for mercury occurred at $\mathrm{pH} 4$ to 5 .

The influence of $\mathrm{pH}$ on $\mathrm{Pb}(\mathrm{II})$ and $\mathrm{Hg}$ (II) removal may be explained as follows. A pure carbon surface is considered to be non-porous but in actual practice some carbon-oxygen complexes such as $\mathrm{CxO}, \mathrm{COx}$, and $\mathrm{CxO}_{2}$ are usually present which render the surface slightly polar ${ }^{8}$. Based upon the work of frumkin ${ }^{9}$ the surface oxide groups available on the surface of a carbon can undergo hydrolytic reaction with the result proton exchangeable sites such as $\mathrm{CxOH}_{2}^{2+}, \mathrm{CxOH}^{+}$may be formed. Since CSC was prepared upon treatment with sulphuric acid groups such as $\mathrm{CxOH}^{+}, \mathrm{CxOH}_{2}{ }^{2+}$ and $\mathrm{CxSO}_{3} \mathrm{H}$ may also be present. Hence it is expected that $\mathrm{H}^{+}$in the group got exchanged with $\mathrm{Pb}^{2+}$ and $\mathrm{Hg}^{2+}$ and soluble complexes of $\mathrm{Pb}(\mathrm{II})$ and $\mathrm{Hg}(\mathrm{II})$ as follows.

$$
\begin{aligned}
2 \mathrm{CxOH}^{+}+\mathrm{Pb}^{2+} \rightarrow(\mathrm{CxO})_{2} \mathrm{~Pb}^{2+}+2 \mathrm{H}^{+} \\
2 \mathrm{CxOH}^{+}+\mathrm{Hg}^{2+} \rightarrow(\mathrm{CxO})_{2} \mathrm{Hg}^{2+}+2 \mathrm{H}^{+} \\
\mathrm{CxOH}_{2}{ }^{2+}+\mathrm{Pb}^{2+} \rightarrow \mathrm{CxO} \mathrm{Pb}^{2+}+2 \mathrm{H}^{+} \\
\mathrm{CxOH}_{2}{ }^{2+}+\mathrm{Hg}^{2+} \rightarrow \mathrm{CxOHg}^{2+}+2 \mathrm{H}^{+}
\end{aligned}
$$

\section{Effect of carbon dosage}

Figures 3-6 show the simultaneous removal of $\mathrm{Pb}(\mathrm{II})$ and $\mathrm{Hg}(\mathrm{II})$ as a function of carbon dosage by CSC. It is evident that $99 \%$ removal of both metals could be achieved for an initial concentration of $10 \mathrm{mg} / \mathrm{L}$ of $\mathrm{Pb}$ (II) and $\mathrm{Hg}$ (II) ions in $100 \mathrm{~mL}$, with a carbon dosage of $100 \mathrm{mg}$. Higher levels of removal capacity may be due to larger surface area and moderate ion exchange capacity.

In order to find out whether the increase in the concentration of $\mathrm{Hg}(\mathrm{II})$ affects lead adsorption solutions containing $\mathrm{Pb}$ (II) and $\mathrm{Hg}$ (II) were prepared in the ratio 1:2, 1:3, 1:4. It could be seen that quantitative removal was maintained in the case of $\mathrm{Pb}$ (II) whereas $\mathrm{Hg}$ (II) removal came down from 99 to $95 \%$ 


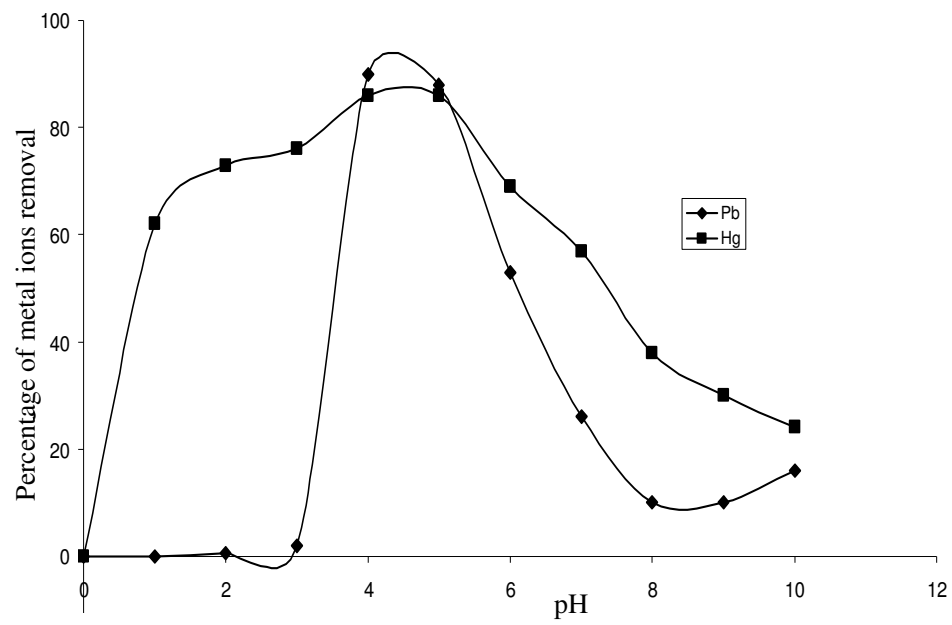

Figure 2. Effect of $\mathrm{pH}$.

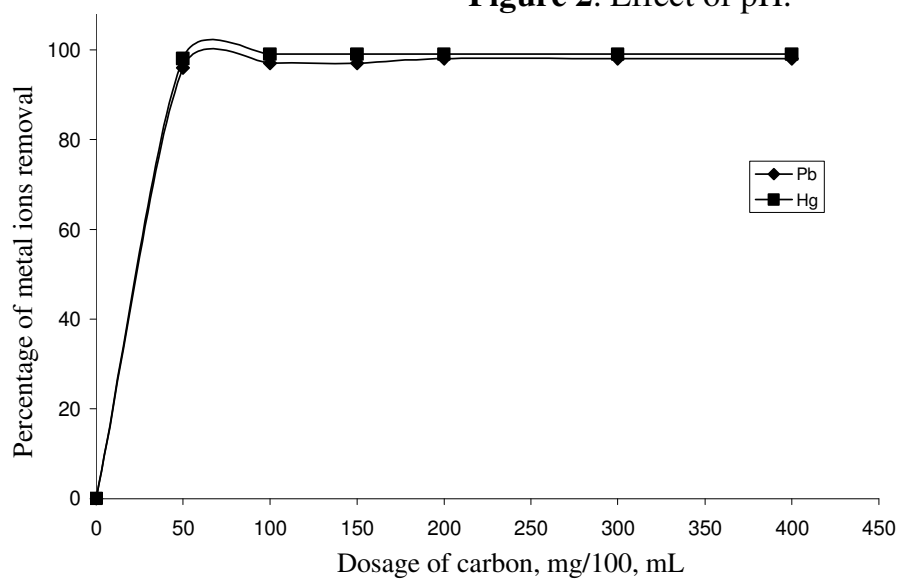

Figure 3. Effect of carbon dosage.

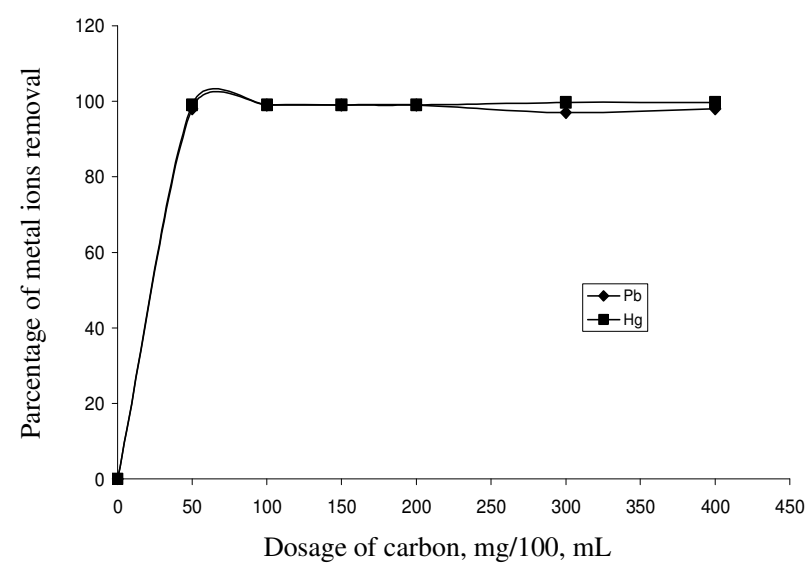

Figure 4. Effect of carbon dosage (1:2) for $\mathrm{Pb}: \mathrm{Hg}$ solution. 


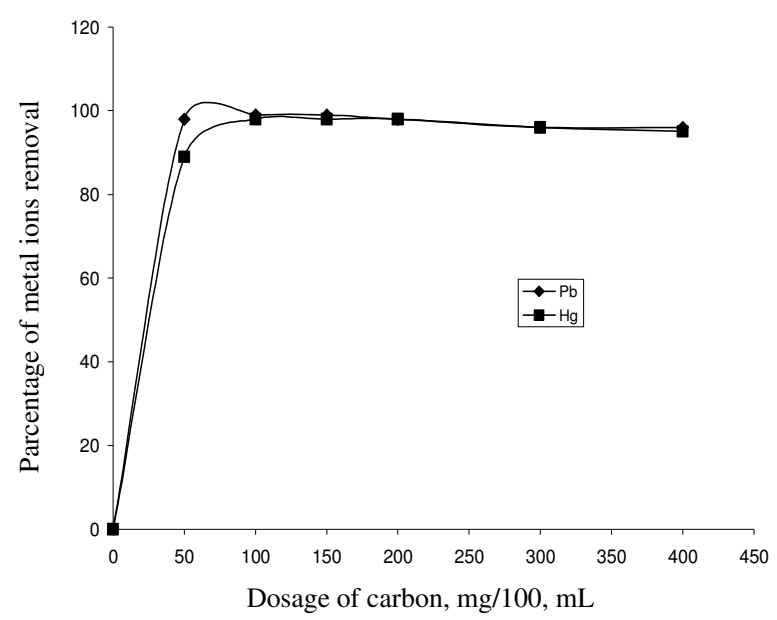

Figure 5. Effect of carbon dosage (1:3) for $\mathrm{Pb}: \mathrm{Hg}$ solution.

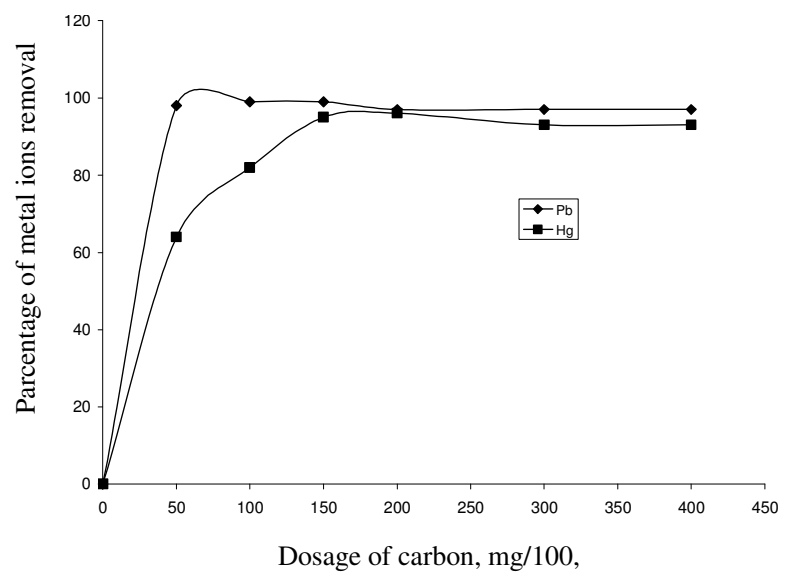

Figure 6. Effect of carbon dosage (1:4) for $\mathrm{Pb}: \mathrm{Hg}$ solution.

\section{Adsorption isotherms}

The Langmuir equation was applied for adsorption equilibrium for both $\mathrm{Pb}$ (II) and $\mathrm{Hg}$ (II).

$$
\mathrm{C}_{\mathrm{e}} / \mathrm{q}_{\mathrm{e}}=1 / \mathrm{Q}_{\mathrm{o}} \mathrm{b}+\mathrm{C}_{\mathrm{e}} / \mathrm{Q}_{\mathrm{o}}
$$

where, $\mathrm{C}_{\mathrm{e}}$ is the equilibrium concentration $(\mathrm{mg} / \mathrm{L}), \mathrm{q}_{\mathrm{e}}$ is the amount adsorbed at equilibrium $(\mathrm{mg} / \mathrm{L})$ and $\mathrm{Q}_{\mathrm{o}}$ and $\mathrm{b}$ are Langmuir constant related to adsorption capacity and energy of adsorption respectively. The linear plots $\mathrm{C}_{\mathrm{e}} / \mathrm{q}_{\mathrm{e}} v s . \mathrm{C}_{\mathrm{e}}$ shows that the adsorption obeys the Langmuir model for both $\mathrm{Pb}(\mathrm{II})$ and $\mathrm{Hg}(\mathrm{II})$ and it is shown in Figures $7 \& 8 . \mathrm{Q}_{\mathrm{o}}$ and $\mathrm{b}$ were determined from the Langmuir plots and found to be $48.31 \mathrm{mg} / \mathrm{g}$ and $4.31 \mathrm{mg} / \mathrm{L}$ respectively for $\mathrm{Pb}$ (II) in distilled water and $33.00 \mathrm{mg} / \mathrm{g}$ and $0.168 \mathrm{mg} / \mathrm{L}$ respectively for $\mathrm{Pb}$ (II) in tap water. $\mathrm{In}$ the case of $\mathrm{Hg}(\mathrm{II}), 7.246 \mathrm{mg} / \mathrm{g}$ and $6.899 \mathrm{mg} / \mathrm{L}$ were found out respectively for $\mathrm{Hg}(\mathrm{II})$ in distilled water and $36.00 \mathrm{mg} / \mathrm{g}$ and $3.613 \mathrm{mg} / \mathrm{L}$ respectively for $\mathrm{Hg}$ (II) in tap water. The essential characteristics of Langmuir isotherm can be expressed in terms of a dimensionless constant separation factor (or) equilibrium parameter. $R_{L}$ which is shown as $R_{L}=1 /\left(1+b C_{o}\right)$ where, $b$ is Langmuir constant and $\mathrm{Co}$ be the initial concentrations of $\mathrm{Pb}$ (II) and $\mathrm{Hg}$ (II). $\mathrm{R}_{\mathrm{L}}$ values are shown in Table 2. The values of $1<\mathrm{n}<10$ show favorable adsorption of $\mathrm{Pb}$ (II) and $\mathrm{Hg}$ (II) on $\mathrm{CSC}^{8}$. 


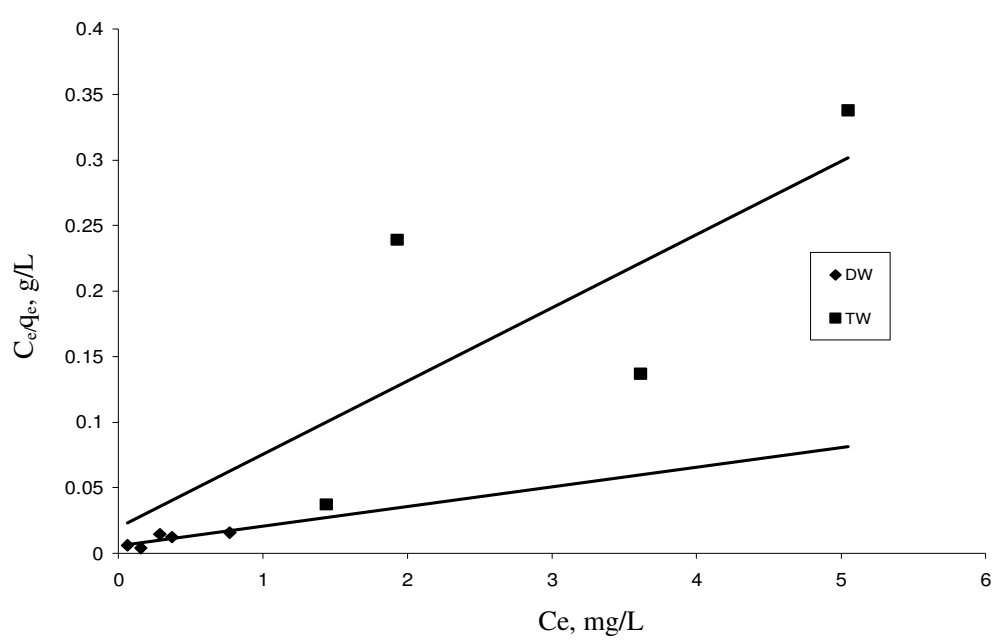

Figure 7. Langmuir adsorption isotherm for $\mathrm{Pb}(\mathrm{II})$.

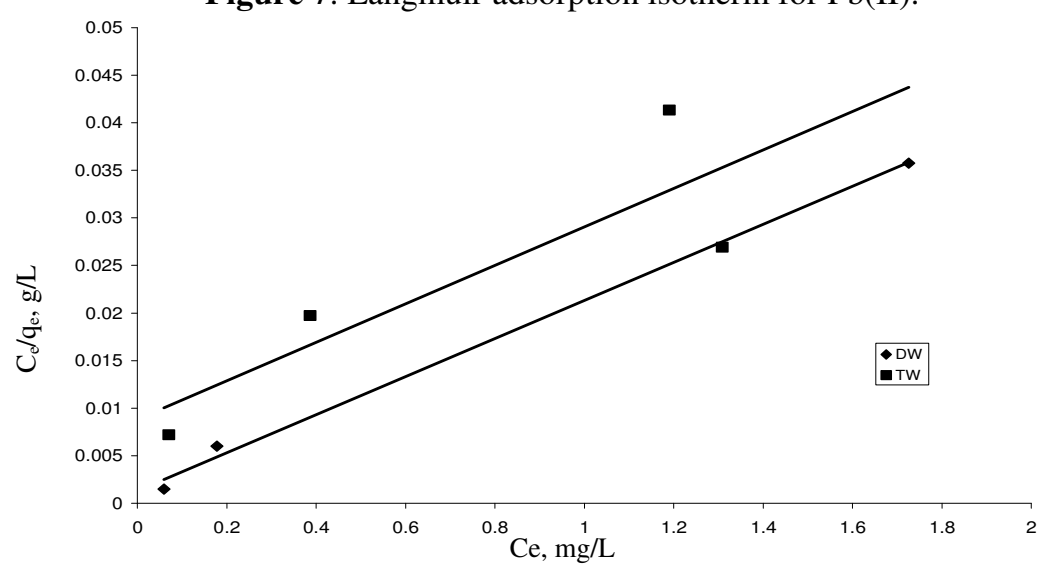

Figure 8. Langmuir adsorption isotherm for $\mathrm{Hg}(\mathrm{II})$.

Table 2. $\mathrm{R}_{\mathrm{L}}$ values for $\mathrm{Pb}(\mathrm{II})$ and $\mathrm{Hg}(\mathrm{II})$.

\begin{tabular}{cccccc}
\hline S.No. & $\begin{array}{c}\text { Concentration } \\
\text { in } \mathrm{mg} / \mathrm{L}\end{array}$ & \multicolumn{2}{c}{$\mathrm{R}_{\mathrm{L}}$ values, Distilled water } & \multicolumn{2}{c}{$\mathrm{R}_{\mathrm{L}}$ values (Tap water) } \\
\cline { 2 - 6 } & 10 & 0.01882 & 0.01266 & 0.08562 & 0.02167 \\
\hline 1 & 20 & 0.00941 & 0.00633 & 0.04281 & 0.01084 \\
2 & 30 & 0.00627 & 0.00422 & 0.02854 & 0.00723 \\
3 & 40 & 0.00471 & 0.00316 & 0.02140 & 0.05419 \\
4 & 50 & 0.00376 & 0.00253 & 0.01712 & 0.00434 \\
5 &
\end{tabular}

The Freundlich isotherm is represented by the equation ${ }^{8}$

$$
\log \mathrm{x} / \mathrm{m}=\log \mathrm{K}+1 / \mathrm{n}\left(\log \mathrm{C}_{\mathrm{e}}\right)
$$

Where $\mathrm{C}_{\mathrm{e}}$ is the equilibrium concentration $(\mathrm{mg} / \mathrm{L})$ and $\mathrm{x} / \mathrm{m}$ is the amount adsorbed per unit weight of CSC (mg/g). Plots of $\log \mathrm{x} / \mathrm{m} v s . \log \mathrm{C}_{\mathrm{e}}$ are linear for both metal ions. Figures $9 \& 10$ show the Freundlich adsorption isotherm for $\mathrm{Pb}(\mathrm{II})$ and $\mathrm{Hg}$ (II) metal ions in tap water 
and distilled water. The processes followed were of Freudlich adsorption type. The ' $K$ ' and ' $n$ ' values for both metal ions were calculated from the intercepts and slopes, respectively and shown in Table 3. It could be seen that $\mathrm{Pb}$ (II) and $\mathrm{Hg}$ (II) removal was found to be more in distilled water when compared with tap water. The decrease in removal may be due to competition of common ions available in water for the sites of lead and mercury.

Table 3. K and $\mathrm{n}$ values of Freundlich adsorption isotherm.

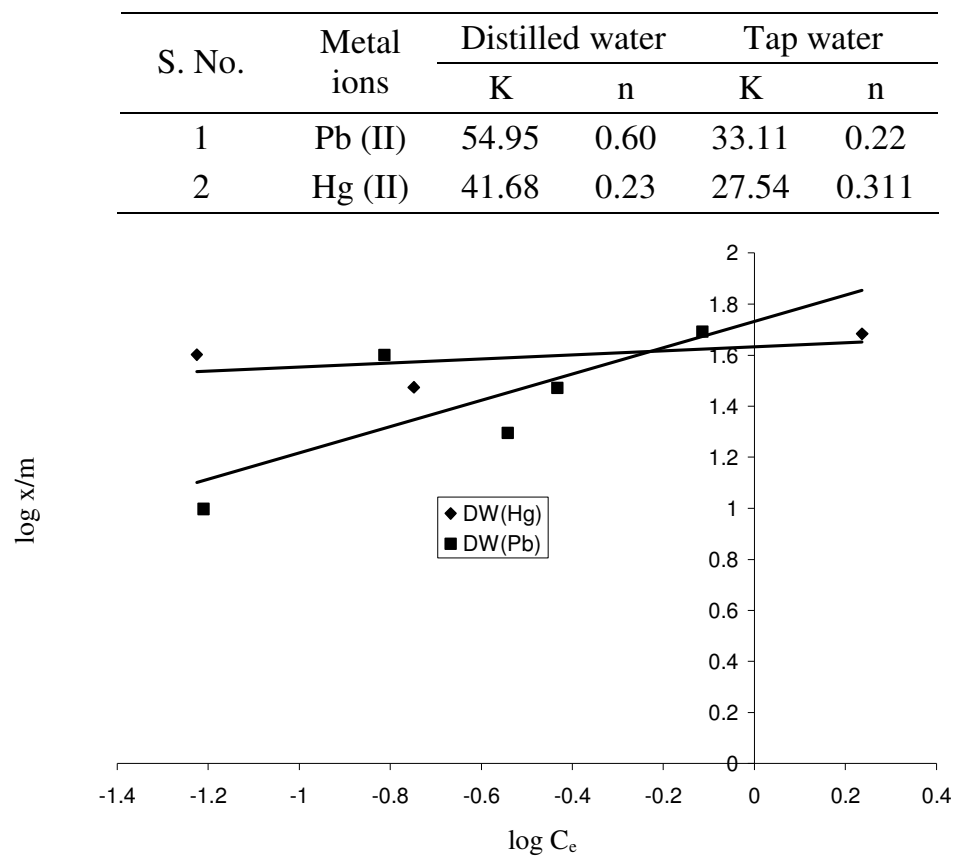

Figure 9. Freundlich adsorption isotherm in distilled water.

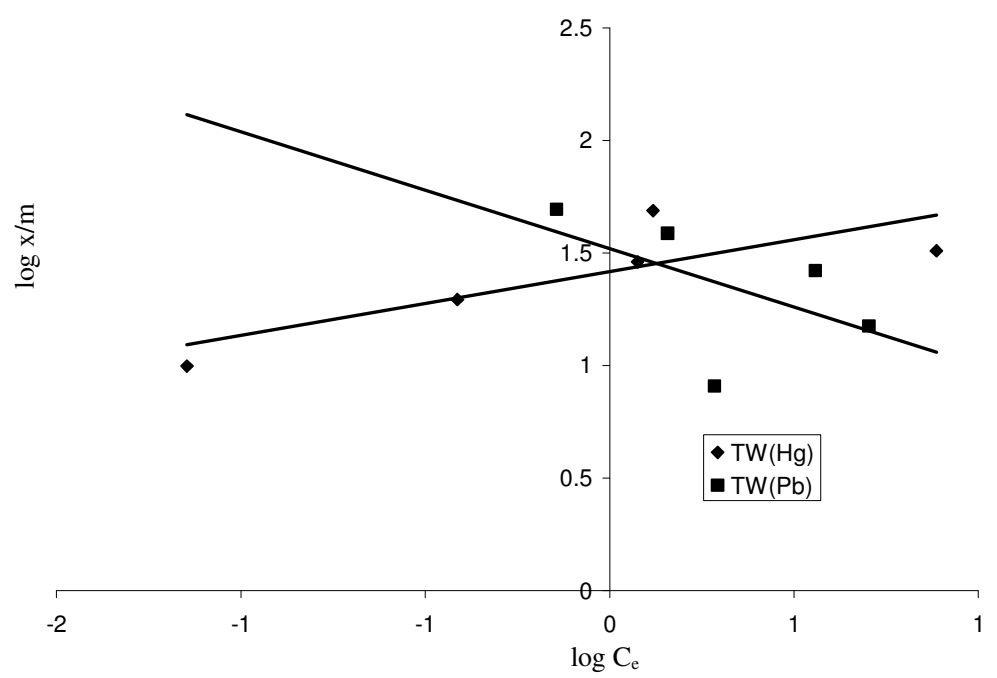

Figure 10. Freundlich adsorption isotherm in tap water. 


\section{Adsorption kinetics}

The kinetics of bimetal adsorption follows the first order rate expression. The kinetic fits for both metal ions are shown in Figures $11 \& 12$. The detailed mathematical derivations for calculating the reversible first order kinetics and the values of film and pore diffusion coefficient are described elsewhere ${ }^{9}$. The kinetic data are furnished in Table 4. Since the forward rate constants are much higher than the backward rate constants for the heavy metals under consideration, it could be concluded that adsorption is a well favored process. According to Michelsen et al., if the film diffusion is the governing process of adsorption on carbon, then the coefficient $\left(D_{\mathrm{f}}\right)$ value should be between $10^{-6}-10^{-8} \mathrm{~cm}^{2} / \mathrm{sec}$. If pore diffusion $\mathrm{Dp}$ were to be rate determining, its values should be in the range $10^{-11}-10^{-13} \mathrm{~cm}^{2} / \mathrm{sec}$. Using kinetic data, the values for film and pore diffusion constants were calculated and shown in Table 5. It is evident that the removal of $\mathrm{Pb}$ (II) and $\mathrm{Hg}$ (II) follow film diffusion process as outlined by Michelsen since the co-efficient values are very close to the range of $10^{-8} \mathrm{~cm}^{2} / \mathrm{sec}$.

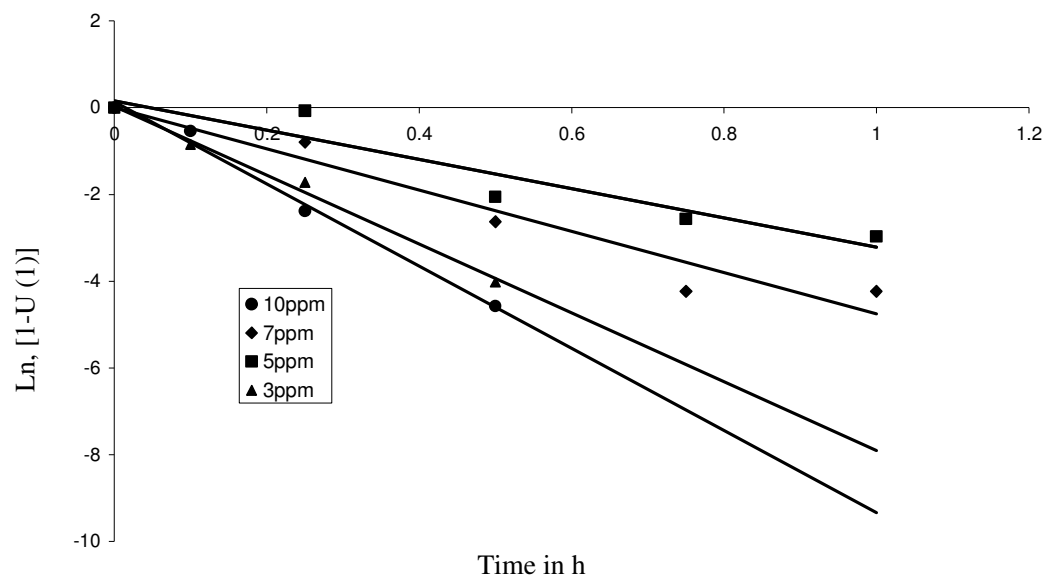

Figure 11. Kinetic fits of lead.

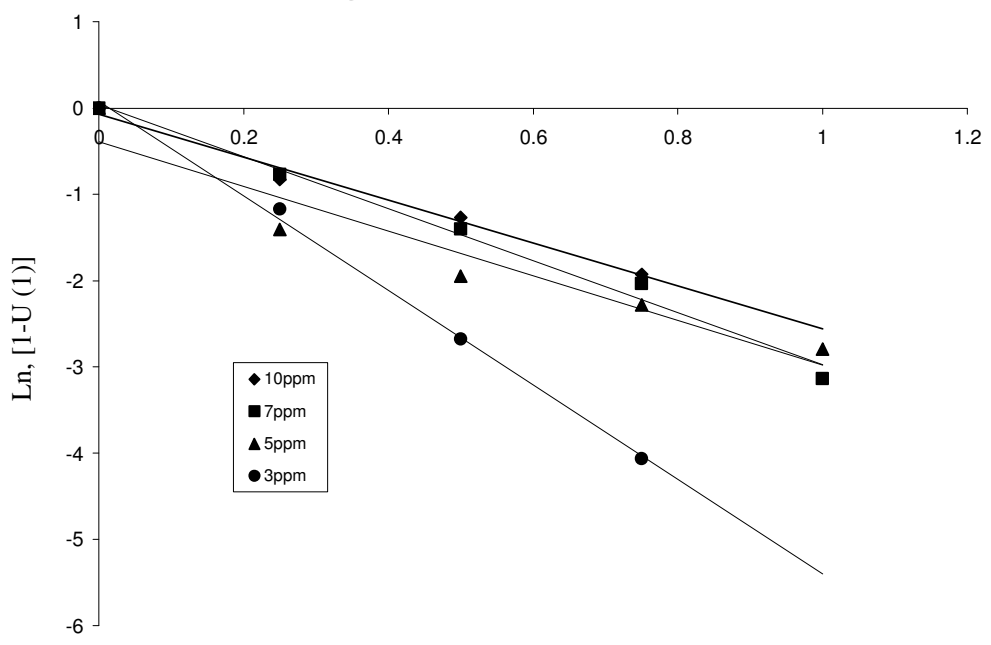

Time in $\mathrm{h}$

Figure 12. Kinetic fits of mercury. 
Table 4. Rate constants for the removal of lead and mercury (CSC).

\begin{tabular}{ccccccc}
\hline \multirow{2}{*}{$\begin{array}{c}\text { Concentration of } \\
\text { metal ions, mg/L }\end{array}$} & \multicolumn{2}{c}{$\begin{array}{c}\mathrm{K} \text {, overall rate } \\
\text { constant }\end{array}$} & \multicolumn{2}{c}{$\begin{array}{c}\mathrm{K}_{1} \text {, forward } \\
\text { rate constant }\end{array}$} & \multicolumn{2}{c}{$\begin{array}{c}\mathrm{K}_{2} \text {, backward } \\
\text { rate constant }\end{array}$} \\
\cline { 2 - 7 } & $\mathrm{Pb}(\mathrm{II})$ & $\mathrm{Hg}(\mathrm{II})$ & $\mathrm{Pb}(\mathrm{II})$ & $\mathrm{Hg}(\mathrm{II})$ & $\mathrm{Pb}(\mathrm{II})$ & $\mathrm{Hg}(\mathrm{II})$ \\
\hline 10 & 9.20 & 2.50 & 8.92 & 2.39 & 0.27 & 0.10 \\
7 & 5.60 & 2.89 & 5.52 & 2.84 & 0.08 & 0.04 \\
5 & 3.60 & 3.75 & 2.80 & 3.67 & 0.79 & 0.07 \\
3 & 8.00 & 5.31 & 7.46 & 5.14 & 0.53 & 0.17 \\
\hline
\end{tabular}

Table 5. Diffusion co-efficient for the simultaneous removal of lead(II) and mercury(II) by CSC.

\begin{tabular}{ccccc}
\hline \multirow{2}{*}{$\begin{array}{c}\text { Concentration } \\
\text { of metal ions, } \mathrm{mg} / \mathrm{L}\end{array}$} & \multicolumn{2}{c}{ Film diffusion $\times 10^{-10}, \mathrm{~cm}^{2} / \mathrm{s}$} & \multicolumn{2}{c}{ Pore diffusion $\times 10^{-8}, \mathrm{~cm}^{2} / \mathrm{s}$} \\
\cline { 2 - 5 } & $\mathrm{Pb}(\mathrm{II})$ & $\mathrm{Hg}(\mathrm{II})$ & $\mathrm{Pb}(\mathrm{II})$ & $\mathrm{Hg}(\mathrm{II})$ \\
\hline 10 & 7.3179 & 2.6505 & 9.1474 & 2.4849 \\
7 & 2.1196 & 1.0942 & 5.5638 & 2.8724 \\
5 & 2.0992 & 1.9879 & 3.5782 & 3.7273 \\
3 & 1.4140 & 4.6989 & 7.9538 & 5.2863 \\
\hline
\end{tabular}

\section{Conclusion}

The results have clearly demonstrated that cottonseed carbon could be employed successfully for the simultaneous removal of mercury and lead. The carbon has moderate hardness and surface area so that it can be applied for wastewater treatment containing heavy metals such as lead and mercury.

\section{References}

1. Ravera O, Lead Pollution in air and water, FEG Information, Blatt Nr., 1974, 21, 46-54.

2. Kaiser G and Tolg G, Mercury In: The Hand Book of Environmental Chemistry, Anthropogenic compounds, Part-A, Springer-Verlag, Berlin Heidelberg, New York, 1980, 3.

3. Berglund F and Berlin M, Chemical Fallout, Thomas publishers Springfield, 1969, 111.

4. Tanner J T and Freedman M H, J Radioanal Chem., 1977, 37, 395.

5. Frumkin A, Kolloid-2, 1930, 51123.

6. Srinivasan K, Balasubramanian N and Ramakrishna T V, Indian J Environ Health, 1988, 30, 376-389.

7. Arulanantham A, Balasubramanian N and Ramakrishna T V, Metal Finishing, 1989, 87, 51-56.

8. Shukla S S, Li J Y, Doris K L and Shukla A, J Hazard Mater., 2005, 121, 243-246.

9. Yenky M K N and Natarajan G S, Sep Sci Technol., 1991, 26(5), 661-674. 


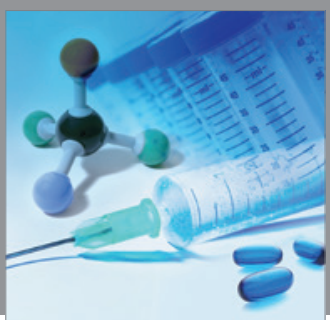

International Journal of

Medicinal Chemistry

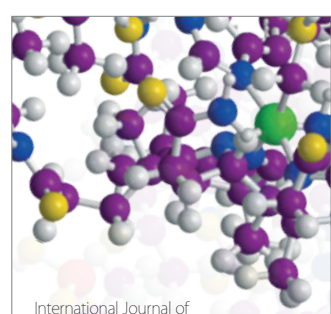

Carbohydrate Chemistry

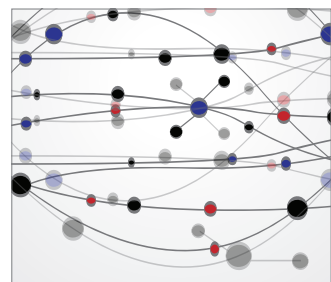

The Scientific World Journal
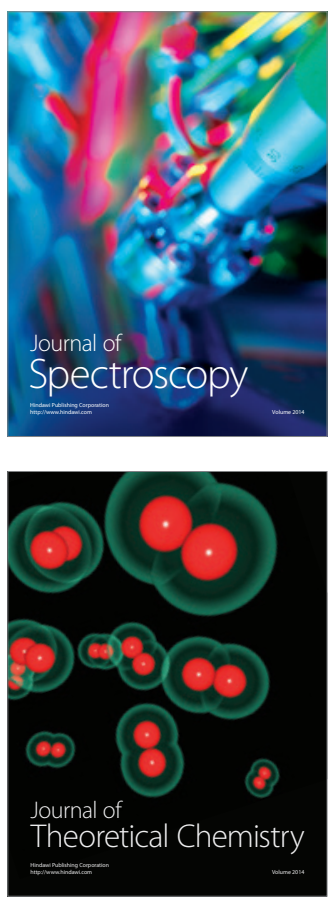
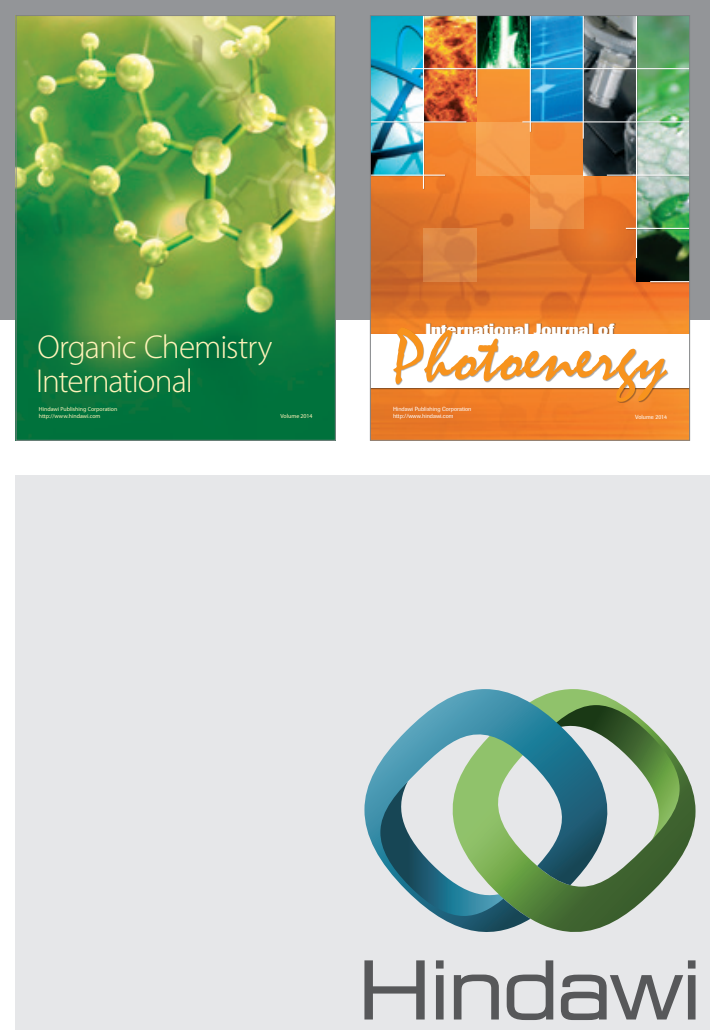

Submit your manuscripts at

http://www.hindawi.com
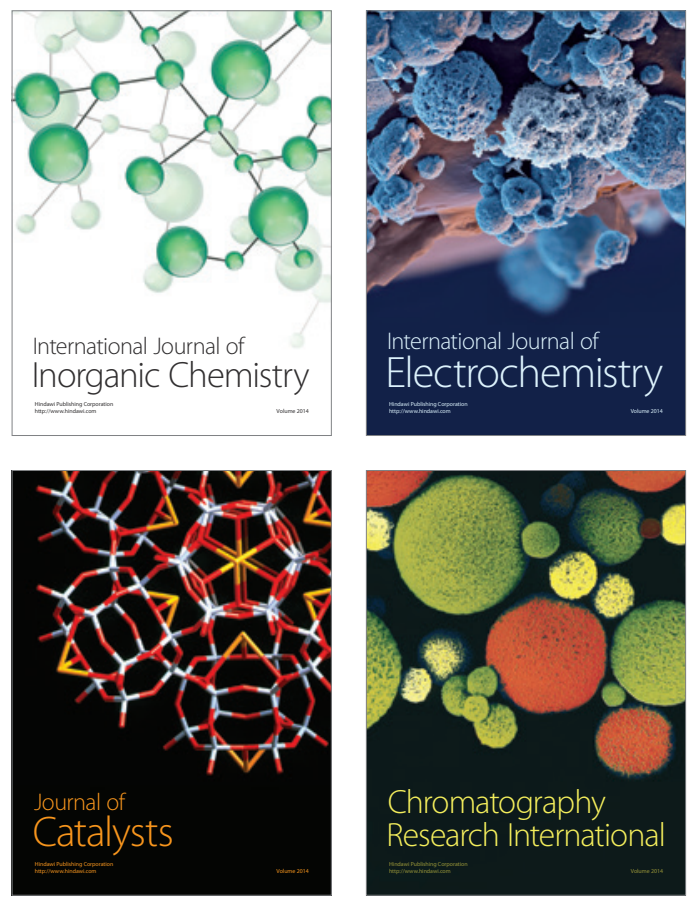
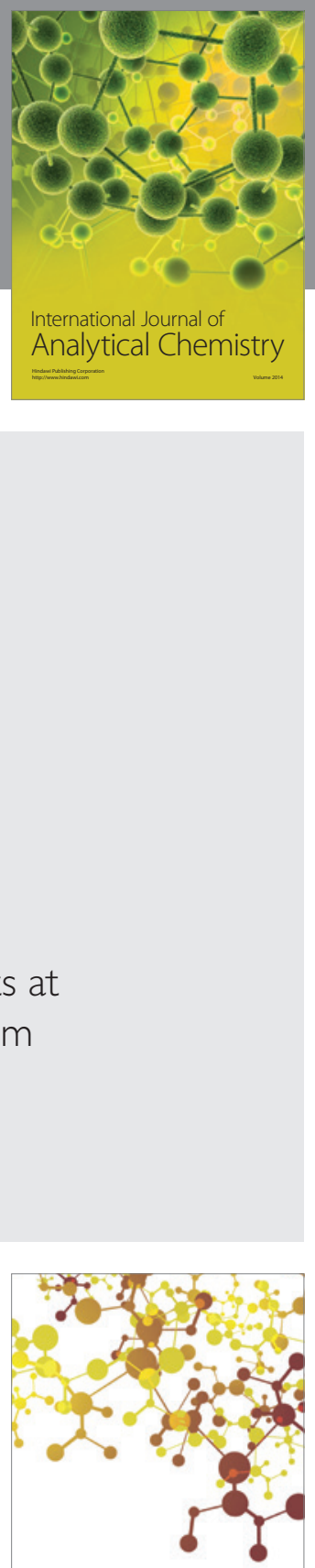

Journal of

Applied Chemistry
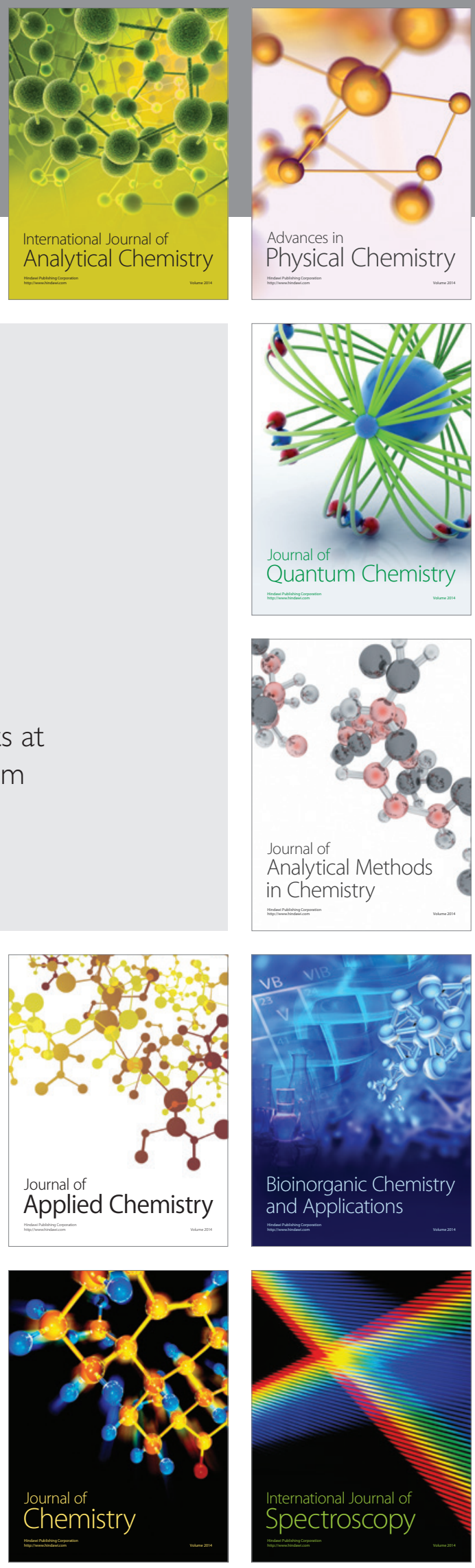